\title{
Community governance with habitus in bonding to prevent SARS-CoV-2 pandemic transmission
}

Tiyas Nur Haryani

Department of Public Administration Faculty of Social and Political Sciences, Universitas Sebelas Maret, Indonesia

Email: tiyasnurharyani@staff.uns.ac.id

\begin{abstract}
Many areas at lowest level like kampong and village have initiatives in community governance terminology to prevent the SARS-CoV-2 transmission in their neighborhood formerly constituting green zone. Community governance will be followed by bonding containing habitus inherent to society structure. This research was conducted in some villages throughout Surakarta Ex-Residency, involving observation and documentattion in Gatak, Banaran, Mojolaban Sub District of Sukoharjo Regency, Karangpandan Sub District of Karanganyar Regency and Kranggan Village of Polanharjo Sub District of Klaten Regency. Data was collected through interview, observation, and documentation. The result of study showed that innovation and productivity arose in community governance in Kranggan Village of Klaten Regency, as indicated with the presence of Karantani program. It is the planting or farming program for Persons under Surveillance or nomads (wanderers) going back to their village. Community leadership, community empowerment and community ownership arise in community governance in Kranggan Village. Furthermore, people should rekindle habitus related to embung (water reservoir), lumbung (communal rice barn), and saung (hut) post-pandemic considered as important in this Covid-19 pandemic period.
\end{abstract}

Keywords: Bonding Social Capital; Community governance; Covid-19; Habitus; SARS-CoV-2 


\section{Introduction}

Pandemic starting on December 2019 is reported in the presence of some disease cases with acute pneumonic symptoms in Wuhan City, Hubei province, People's Republic of China. It has been recognized only on January 7, 2020 that the disease is caused by a virus called Severe Acute Respiratory Syndrome Coronavirus 2 (SARS-CoV-2) (Wu X, Cai Y, Huang X, Yu X, Zhao L, Wang F, 2020). This new virus in fact is deadly and transmittable. Until this writing completion on May 29, 2020, there have been 5,596,550 confirmed cases throughout world and 353,373 (World Health Organization, 2020). Meanwhile, in Indonesia there have been 24,538 confirmed cases and 1,496 deaths (Covid-19 Management Acceleration Task Force, 2020). Disclaimers data is, among others, that they have been tested by the authorized one.

Indonesia, through its government, reported its first case on March 3, 2020. However, some researchers believe that Coronavirus Disease 2019 (Covid-19) case has been existing since January 2020 in Indonesia. Data confusion, data openness, readiness and responsiveness aspect of policy makers in coping with pandemic becomes Indonesia's experience in current SARS$\mathrm{CoV}-2$ pandemic period. Indonesian people question the central government's slowness. Polemic at national level in Indonesia is related not only to novel SARS-CoV-2 variant but also to transmission, management at central level, coordination in decentralization, and its effect on many other fields in crosscutting issue manner.

The mapping of problems arising in SARS-CoV-2 management in Indonesia consists of aspects. Firstly, ignorance of virus structure and its transmission among Indonesian officials in the beginning of pandemic, in fact, endanger their people later. In the beginning of SARS-CoV-2 epidemic period in Wuhan city, Hubei province, People's Republic of China, Indonesian government has not shown off its alertness to it, as indicated with no public information openness to the public concerning this new virus and no restriction for tourists coming from epidemic states (Djalante, 2020). So, on February 27, 2020, Republic of Indonesia's governmental officials, through Minister of Transportation, Budi Karya Sumadi in his interview with mass media, gave statement about coronavirus incapable of entering into Indonesia because Indonesians love consuming nasi kucing, thereby having good body immunity (Hakim, 2020). This statement was an undue joke. Then, on early March 2020, a paradoxical information was given by the Minister of Health, Terawan Agus Putranto, saying that healthy people do not need to wear mask (Ihsanuddin, 
2020). This statement, in turn, changes into an appeal to everyone to wear mask in preventing this transmission of SARS-CoV-2 virus.

Secondly, the situation above is getting more complicated when pandemic entered into Indonesia. Indonesian government has inadequate fund source to cope with the effect of Covid-19. Indonesia with the population number of 273 millions people is estimated to need fund of IDR 405.1 trillions or US\$25.3 billions (foreign exchange rate US\$ $1=$ IDR 16,000) to cope with Coronoavirus effect. Fund source insufficiency is only one of factor causing Indonesian government's hesitation to deal with Covid-19.

Thirdly, Indonesia as an archipelago country faces some challenges in the procedure of preventing and managing pandemic effect. Distribution of drug, medical equipment, and food staple logistic plays an important role. Broad area and extreme field are predicted to make the distribution to rural areas difficult. It is also true for the distribution of Covid-19 related information. Hoax dissemination within community is the fourth problem contributing to the complexity of Covid-19 pandemic prevention and management in Indonesia.

Fifthly, the next problem is poor collaboration and synergy between regions in decentralization system concerning social and physical distancing policy and region lockdown. Surakarta City is the first region to establish and to release public information on SARS-CoV-2 extraordinary case. Social distancing is enacted in Surakarta City from March 14, 2020 by substituting online learning activity for the conventional one for the students in Surakarta City, determining work from home for state civil servants in Surakarta City government, and restricting the opening hour of stores, cafes, and street sellers. Three following days, Republic of Indonesia's President, Joko Widodo has just held a press conference to appeal the importance of social distancing. Only on March 31 did President Joko Widodo officially publish Republic of Indonesia's Governmental Regulation Number 21 of 2020 about Large-Scale Social Distancing (Pembatasan Social Berskala Besar, thereafter called PSBB) in the attempt of Accelerating Coronavirus Disease-19 (Covid-19) Management. At the same time, the President published Republic of Indonesia Presidents' Decree Number 11 of 2020 about the Establishment of Coronovirus Disease 2019 (Covid-19) Public Health Emergency. The publication of both regulations is based on Republic of Indonesia's Law Number 6 of 2018 about Health Quarantine called PSBB, as the part of public health emergency response. Republic of Indonesia Presidents' Decree Number 11 of 2020 about the Establishment of Coronovirus Disease 2019 (Covid-19) Public Health Emergency 
assigns Covid-19 as a type of disease resulting in public health emergency, the management of which should be conducted obligatorily corresponding to the provision of legislation.

Jakarta is the first city to establish PSBB policy on April 10, 2020. However, it is considered as less effective because some other regions have not enacted it yet or instead have relieved physical distancing policy when it is enacted in Jakarta Capital, so that the people living in Jakarta can move or go back to the other regions before the publication of PSBB policy. For example, the interval time between KLB and Extraordinary Case policy determined by regional governments is not synergistic. Surakarta Ex-residency areas (Solo/ Surakarta, Boyolali, Sukoharjo, Wonogiri, Klaten, Sragen, and Karanganyar) or called Soloraya (Solo Greater Area) have implemented physical distancing policy first and it has been completed within 14 days, despite the extension eventually. It gives some regions to welcome the people coming from Jakarta City before PSBB is enacted in Jakarta.

Decentralization provides the gap of policies released by Local Leader adapting to their regions' condition. Meanwhile, geographical condition of Indonesia, urbanization current, and population mobilization make the first case transmission occurring different between one area and another. Therefore, KLB or lockdown or PSBB policy can be established at different times between regions. Urbanization occurs due to dichotomy between rural and urban areas, so that urbanization and mudik (home to the village) current will occur annually in Indonesia. Moreover, the SARS-CoV-2 pandemic period coincides with Eid al Fitr Day of 1441 Hijriyah. In addition, it is also because of the lowered or stopped economic activities in metropolitan city.

The sixth factor is the public's low compliance with physical distancing, mask wearing, and PSBB. Public's low compliance becomes the challenge in preventing the transmission of SARS-CoV-2 virus, moreover in asymptomatic case (Bai Y, Yao L, Wei T, 2020). All of these conditions result in anxiety among the people in the regions formerly still green zone. Indonesian Government's hesitation to establish policy responsively and public's low compliance contribute to local transmission and even community transmission incidence.

People's anxiety with SARS-CoV-2 transmission leads each of smallest areas in a city/regency, i.e. kampong/village, to make policy in their own area. Community, through its social order, feels the need for playing its strategic role. In governance paradigm, government, private, and community elements are important aspects in solving public problem. People (community) can 
take a part in organizing its community in dealing public problem occurring. When community claim any services that local government cannot fulfill it, communities effort to make self-supporting and play along to each other to fulfill their requirement (Kushandajani, 2014). Community governance contains social capital with bonding within community being the first element. In bonding, social capital will inseparable from the habitus they have and structured collectively.

The development of paradigm from government to governance has an implication to the actor's greater participation in governance. Governanceconstructing institutions include state, private sector and civil society. The three elements synergize and interact with each other corresponding to its own functions and capacities in the organization of public service within community. Openness and participation encourage the change of governmentinto-governance paradigm. Terminologically, governance contains process, activity, and public problem solving substances needing public participation (Sudarmo, 2015).

The reinforcement of civil community sector results from the opened participation arena giving the community group an opportunity of participating in solving public problem. Thus community governance can be seen as local government working with a broad range of other government and community stakeholders to determine preferred futures, and to facilitate shared decisions and joint action to achieve agreed outcomes, including the quality of the local environment and how communities access the services they need (McKinlay P., Pillora, S., Tan, S.F., Von Tunzelmann, 2011). Community governance concept has been developing very rapidly since 1990s to compensate public sector governance (Kushandajani, 2014).

In community governance, the word community can be seen as the form of village citizen, association, and network. Community governance is inseparable from the existence of local governance. Community governance is the community (people)'s consciousness of activating themselves collectively, aiming to change the social-economic condition of local community, considering government and private's role (Pratomo, 2019). Theoretically, community governance can be defined as management, governance, and decision making at community level conducted by, with, or on behalf of community, by a group of community's stakeholders (Kushandajani, 2014). Community governance concept can be applied to the smallest power scope, e.g. village or kampong 
(Pratomo, 2019). Community-based risk preparedness can occur in public service and political domain aspects (Kustiningsih, 2020).

In community governance, there are three elements: community leadership, community empowerment, and community ownership, each of which has concept limit and dimensions accompanying (Kushandajani, 2014). In addition to those elements, community governance contains social capital owned by the corresponding community. Basically, social capital builds on communitarian with social-cultural potency owned that can encourage innovative and productive behavior (Kustiningsih, 2020). Social capital power will tend to be proportional directly to social bonding created such as kinship and belief in value and norm held on collectively. Bonding will be followed with habitus owned by its community.

Habitus is a product of individual's social structure condition (Bourdieu, 2014). Habitus relates to capital and fields. Capital is defined as resource or quality belonging to an individual or influential social position or social value. Meanwhile, fields are composed of individuals positioned objectively in a series of social relationship, with varying resources (varying capitals), and struggles to achieve prestige, wealth, and power (Bourdieu, 2014).

No previous study discusses community governance in Covid-19 pandemic, either nationally or internationally. Riyanti Djalante discussed Indonesian government's response only to Covid-19 pandemic occurring (Djalante, 2020). Other research in Indonesia only focus on establishing Covid-19 response regulations (Telaumbanua, 2020). Another previous study conducted in Indonesia discussed only the urgency of Covid 19-responsive management generally without special analysis to compare the Covid-19 management in Asian, Europe, and America (Deshwal, 2020). This study complements some studies conducted by University of Gadjah Mada addressing, among others, government response dynamic (Widaningrum, 2020) and social capital reinforcement in Covid-19 mitigation (Kustiningsih, 2020).

\section{Literature Review}

The development of paradigm from government to governance has an implication to the actor's greater participation in governance. Governanceconstructing institutions include state, private sector and civil society. The three elements synergize and interact with each other corresponding to its 
own functions and capacities in the organization of public service within community. Openness and participation encourage the change of governmentinto-governance paradigm. Terminologically, governance contains process, activity, and public problem solving substances needing public participation (Sudarmo, 2015).

The reinforcement of civil community sector results from the opened participation arena giving the community group an opportunity of participating in solving public problem. Thus community governance can be seen as local government working with a broad range of other government and community stakeholders to determine preferred futures, and to facilitate shared decisions and joint action to achieve agreed outcomes, including the quality of the local environment and how communities access the services they need (McKinlay P., Pillora, S., Tan, S.F., Von Tunzelmann, 2011). Community governance concept has been developing very rapidly since 1990s to compensate public sector governance (Kushandajani, 2014).

In community governance, the word community can be seen as the form of village citizen, association, and network. Community governance is inseparable from the existence of local governance. Community governance is the community (people)'s consciousness of activating themselves collectively, aiming to change the social-economic condition of local community, considering government and private's role (Pratomo, 2019). Theoretically, community governance can be defined as management, governance, and decision making at community level conducted by, with, or on behalf of community, by a group of community's stakeholders (Kushandajani, 2014). Community governance concept can be applied to the smallest power scope, e.g. village or kampong (Pratomo, 2019). Community-based risk preparedness can occur in public service and political domain aspects (Kustiningsih, 2020).

In community governance, there are three elements: community leadership, community empowerment, and community ownership, each of which has concept limit and dimensions accompanying (Kushandajani, 2014). In addition to those elements, community governance contains social capital owned by the corresponding community. Basically, social capital builds on communitarian with social-cultural potency owned that can encourage innovative and productive behavior (Kustiningsih, 2020). Social capital power will tend to be proportional directly to social bonding created such as kinship and belief in value and norm held on collectively. Bonding will be followed with habitus owned by its community. 
Habitus is a product of individual's social structure condition (Bourdieu, 2014). Habitus relates to capital and fields. Capital is defined as resource or quality belonging to an individual or influential social position or social value. Meanwhile, fields are composed of individuals positioned objectively in a series of social relationship, with varying resources (varying capitals), and struggles to achieve prestige, wealth, and power (Bourdieu, 2014).

\section{Methods}

This research was conducted using descriptive qualitative approach. Data was collected through interview, documentation and observation in Surakarta City Ex-Residency area with the sample areas taken purposively, i.e. the village areas with innovation in community governance scheme. The data used is qualitative (data that is not in the form of numbers) (Moleong, 2001). Descriptive qualitative approach is used to observe social events and life of community in community governance aspect arising in village areas in Surakarta City Exresidency in coping with SARS-CoV-2 pandemic transmission with bonding and habitus within. The main instrument used in qualitative research is the author itself in its ability of capturing observation, data reduction, documentation, and interview with informants selected using purposive sampling technique and documentation on secondary data source. The informants are selected with the maximum variance technique, representing various categories (Sugiyono, 2014). Data source derived from primary data obtained through unstructured interview with some public figures: society leader and former head of Kranggan Village, Polanharjo Sub District, Klaten Regency, and observation and documentation photograph in village areas in Gatak, Banaran and Mojolaban Sub Districts of Sukoharjo Regency, Kranggan Village of Polanharjo Sub District of Klaten Regency, and Karangpandan Sub District of Karanganyar Regency. Secondary data included phrases suggested by informants and written material originating from books, reports, journals, written and video news on Covid-19 pandemic and social-economic life of Javanese people in the past and present. This research employed source triangulation by matching and comparing the data obtained. Data analysis was conducted through collecting data with interview, observation, and documentation technique, and then data reduction corresponding to the focus and locus of research, data display in narrative form, and conclusion drawing. 


\section{Results and Discussion}

The habitus of past community in its area management reflected its attempt of resisting Covid-19 transmission today. In an interview, N1 stated that "the most important capital to face pandemic is, among others, social preparedness of community members" (interview, March 31, 2020). Most people in Soloraya region deal with Covid-19 pandemic through self-isolation in their own houses. Limited fund, medical resources, and health facilities are main factors need to be considered to establish extraordinary incidence policy in Soloraya. Similarly, Klaten Regency government established its region to have Extraordinary Incidence along with prevention and management procedure on April 1, 2020.

There is something unique in Klaten, in which there is a village providing a place for quarantine communally, innovatively and productively. The village is Kranggan village taking an attempt of managing Covid-19 pandemic transmission from March 16, 2020. Kranggan village is located in Polanharjo Sub District, Klaten Regency, with 102.088 hectare-wide area, occupied with 3,400 populations. Its populations' main livelihoods are blacksmith, farmer, and wanderer (perantau). Kranggan itself is blessed with natural abundant water source (there are some synonyms of water sources: umbul, sendang, telaga and jala, but the author prefers using embung in order to rhyme with kampung, lumbung and saung). Even when a mineral drinking water factory exploits the water source in Kranggan area, the quality and quantity of embung in Kranggan does not change at all.

Kranggan villagers' livelihood highly affects their social behavior. Due to their profession, information flow from Solo city runs smoothly. Kranggan is about $22 \mathrm{~km}$ from Solo City. The road passed through can be Solo-Yogya road or old way crossing the border between Solo and Sukoharjo. This old way is connected directly to Keraton Susuhunan Surakarta. Keraton (Court) people formerly have blacksmiths in Kranggan made keris (kriss dagger). Meanwhile, ordinary people have them (blacksmiths) made farming tools. Kranggan gives an example about how the change of house sketch concept is from Raffle reign period to colonial age to the present. This change of house sketch concept also changes the social behavior of villagers.

When Covid-19 pandemic occurs, Kranggan villagers began to organize themselves. Local policy makers assemble to hold village discussion to make policy in dealing with Covid-19. The village head, Gunawan Budi Utomo, and 
former village head, N2 are the main figures contributing to facing Covid-19 as the manifestation of community leadership. From community leadership, community ownership appears because psychologically, Javanese people prefer hearing the local community leader to hearing the officials at regional or central government level. It is because of the bonding created or the limited literacy of people to study new information circulating, so that the presence of skillful community leaders is very helpful.

N2 stated that Kranggan village provides Kranggan Sport Center to be the quarantine center for pemudik (homecomer) for 14 days. Pemudik goes back to their village because of lowered demand for workers in Covid-19 pandemic red zone. All pemudiks have ODP (person under surveillance) status; therefore they need to be quarantined in their beginning of homecoming. The unique point found in the quarantine model implemented by Kranggan Village is the farm land provided behind the Kranggan Sport Center. Furthermore, N2 stated that this 1-pathok (1000 squared meters) wide farm land provided is the wet one that can be planted with cassava, chili, and other spice plants. Kranggan villagers themselves call this quarantine model "Karantani". Karantani is a portmanteau of words karantina and bertani (quarantine and farming). The word Karantani is ear catchy and understandable to all classes of people.

During this writing process on May 2020, two ODPs entered into Karantani program. They planted chili in polybag and cassava on wet land. All planting media and seeds are provided by villagers. So are the farming tools. Initiative to provide farming tools, quarantine model, and fund are provided independently by villagers. All of ODP's need will be sufficed by the village, taken from all people's dues as the form of community empowerment. The economically-have citizens will contribute dues more than others. It is unsurprising that Kranggan villagers implement their Karantani model by taking from villagers' dues. The past bonding is the key to this event.

Kranggan village with its Karantani is the manifestation of social preparedness during Covid-19 invasion. However, what the Kranggan Villagers present with their Karantani implies another meaning. The aspect of bonding in mutual cooperation (gotong royong) known by Javanese people since ancient time is not defined as team work and solidarity. The factors encouraging bonding in mutual cooperation are moral obligation, obedience to authority, reluctant and shy feeling to neighbor. For that reasons, before stepping further, the bonding that in turn will strengthen teamwork pattern and solidarity in social life of Javanese people should be inculcated. Solidarity is of course based 
on humanity. It is the works performed based on humanity. This cooperation between villagers cross social structures and religions is important to the sustainability of many people's life. Villagers should override their sectoral ego for the sake of many people's better life interest.

The revival of past habitus of kampung, ambung, lumbung and saung during this pandemic period is considered as urgent; therefore bonding in community governance should be strengthened. Bonding will reinforce teamwork pattern and social solidarity, and it will facilitate the kampung people to maintain embung and river, and to build communal barn. The idea of reviving village barn communally reappears today. It will be very good if during pandemic or disaster the village barn can suffice their people's needs. Meanwhile, embung and river maintenance in the city can be indicated with not disposing rubbish haphazardly, managing liquid waste, and developing infiltration wells. Large companies are supervised tightly in the term of its liquid waste processing. In the village, it can be implemented by not using heavy chemicals in farming and by processing liquid waste.

There was gentong and kendi concept as the urban people's form of sharing with foreigners. Now tapped-plastic pail or wash basin reappears in front of house along with liquid soap for hand washing to prevent Covid-19 transmission. This concept builds more on pandemic mitigation. Post-pandemic the concept of maintaining cleanliness by washing hand permanently such as the preexisting habitus should be rethought of.

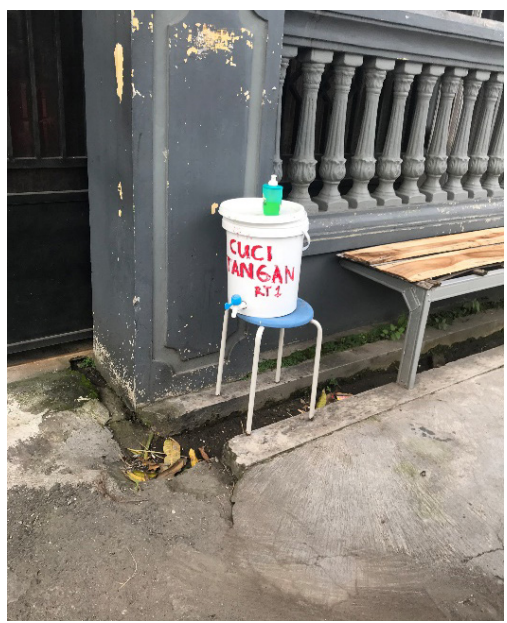

Figure 1: Wash Basin Reapper in Front of House in Gatak Sub District of Sukoharjo Regency 
If social solidarity bonding has been established strongly and confidence has grown, cyberspace communal barns will be created easily in urban areas. Technology 4.0 supports the presence of cyberspace communal barns. Because the narrow land in urban areas disallows the construction of communal barn physically, kampung citizens in urban areas can take aside some of their income to be stored and managed communally in the reliable financial institution. Kampung citizens who want to buy monthly need can use this communal barn. This cyberspace barn (lumbung) in urban areas also restores the trust in the village to manage the urban people's food need. Perhaps gadu system and the similar will be present again.

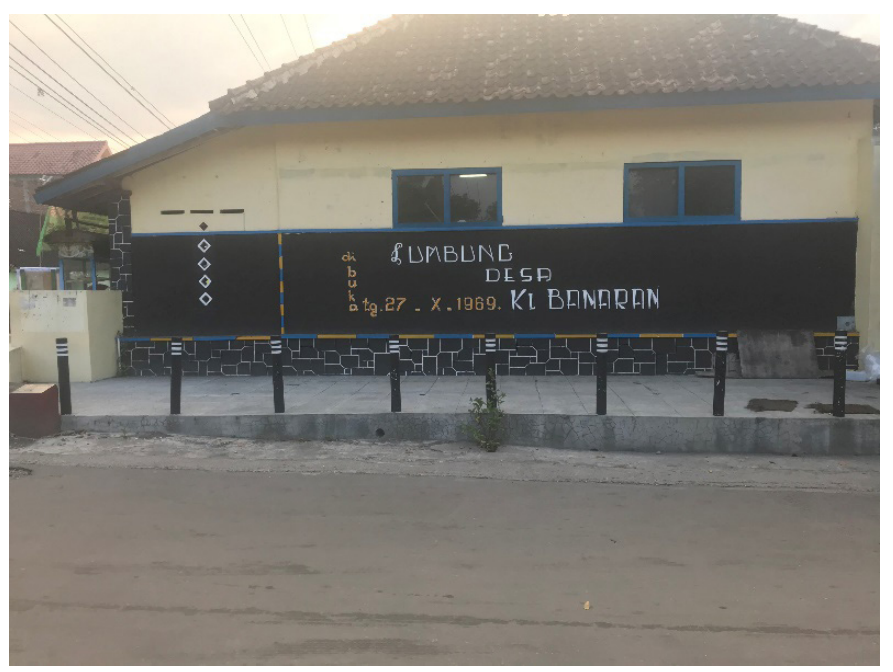

Figure 2: Former Communal Barn Building in Banaran Sub District of Sukoharjo Regency

It is still possible to construct communal barn in the village. However, the construction of communal barn in cyberspace should also be thought of, considering the natural disaster factor and vulnerable-to-conflict areas. The content of barn should not only be paddy and rice. Referring to the past, when the barn also contained cooking oil, sugar, coconut, spice, and seed, it can also contain other crops and durable sea products. An integrated communication system between barns should also be thought of. Thus, human beings' need for protein remains to be fulfilled. The storage indeed still needs barn physically. For that reason, the location should be thought of further, or it can be conducted 
by entrusting it to other regions or to Bulog. Once more time, the feeling of confidence and cooperation in bonding should grow first.

Cyberspace barn can function to break the too-long distribution chain. Thus, the buyer sets not too high price and the seller sets not too low price. Bonding in the form of cooperation (teamwork), solidarity, and trust is the backbone of communal barn functioning. Citizens entrust their crop to be managed by an institution, the members of which are villagers themselves. During quiet period, the barn content can be used to subsidy the poor people in their own regions. This concept will not work if the bonding feeling has not grown yet among kampung citizens. During food scarcity period such as when Covid-19 invades Indonesia today, the content of barn can be used to survive until the pandemic ends actually.

Saung should be rethought of by utilizing technology 4.0 such as CCTV. When people may not assemble but crime rate is high, the utilization of communication through gadget and early warning should be developed. It is a system integrated into local security authority. Portal installation and kentongan reactivation only are not enough. Recently, saung can also be used as a communication media to relieve panic and to grow trust among members of community. As known, the Republic of Indonesia's Minister of Law and Human Rights, Yasonna Laoly, has released (assimilated) the prisoners early on April 1, 2020, to prevent Corona virus transmission in the jail, and to fulfill their right to live. The release of prisoners results in panic within community. Mass media covers the news on criminal case committed by prisoners getting early assimilation program. Meanwhile, when it is investigated further, the crime repetition committed by prisoners released is small in number, out of all prisoners getting assimilation, only 19 becoming recidivist per April 16 (0.0005 percent) (Republika.co.id, 2020). However, it is noteworthy that the economic condition of state three years ago was different from that today when Covid-19 invades. The economy is in trouble now. Massive dismissal begins to be done. People seek for job difficultly. Indeed people should not panic excessively. People need alertness. Saung here functions to relieve panic and to improve alertness. 


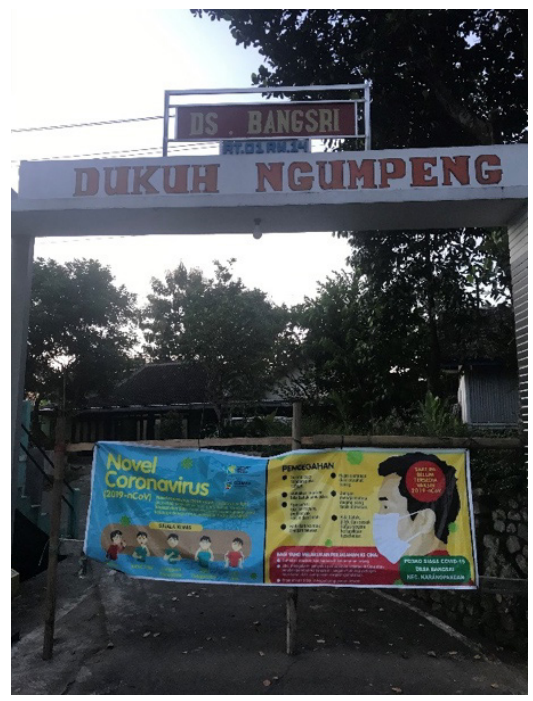

Figure 3: Portal was installed to prevent village in Karangpandan Sub District of Karanganyar

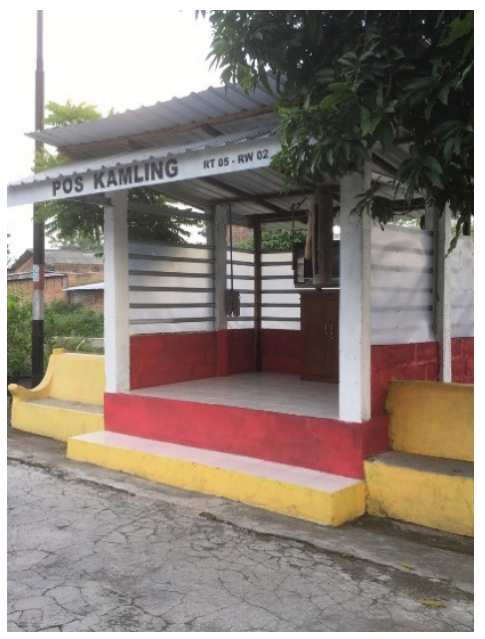

Figure 4: Saung in Mojolaban Sub District of Karanganyar

In addition to lumbung, embung, and saung in citizens' habitus, there is also Short Memory Syndrome problem in which Java land is always invaded with pandemic once in a century, from the $9^{\text {th }}$ to today, but the $14^{\text {th }}$ and $15^{\text {th }}$ centuries (see (Raffles, 1830); (Nastiti, 2016); (Riana, 2009); (de Graff, 1986); (Walcott, 1914)). However, Javanese people keep forgetting to search for the 
way in the process of preventing and coping with pandemic. Short Memory Syndrome should be found for its antidote. Bourdieu explains how to ward off it, through Habitus. Habitus is interpretive schemes, particularly and often working unconsciously, and hiding behind individual's mind.

Habitus gives clues to individuals about how the world works, evaluates many actions, and gives guidance to act. The understanding on theory presupposes that habitus can be changed. The change of habitus should be conducted by considering fields. Some practical ways can be used: education conducted continuously, seminar, disaster and pandemic mitigation simulation, certain folklore development and dissemination, monument development and its commemoration rite, confidence and cooperation inculcation within community can be used to prevent this Short Memory Syndrome from occurring. It is reasonable to consider as the sustainable development in some next generations. This Covid-19 also teaches the people to participate actively in helping the government solve public problem in their environment when the government is overwhelmed. Community's obedience and independency can help prevent SARS-Cov-2 transmission. Community should grow team work ethos and confidence in their social life. Covid-19 teaches the people to recover their dignity as human being and community.

\section{Conclusion}

In modern terminology, community governance can also refer to it by strengthening its bonding. When stakeholders want to reinforce community governance, the feeling of cooperation (teamwork), trust (confidence) and solidarity should be inculcated within community, in order to strengthen the bonding. Bonding reinforcement needs habitus inculcation in the community. Habitus inculcation should be conducted through sustainable education to the community. The community should revive lumbung, and maintain embung and saung through the reinforced bonding and habitus for the next generation postpandemic.

\section{References}

Bai Y, Yao L, Wei T, et al. (2020). Presumed asymptomatic carrier transmission of Covid-19. JAMA, 323( 14). 1406-1407. https://doi.org/doi:10.1001/ jama.2020.2565 
Bourdieu, P. (2014). Menyingkap kuasa simbol. Penerbit Jalasutra.

Covid-19 Management Acceleration Task Force. (2020). Situasi Covid-19 di Indonesia Gugus Tugas Percepatan Penanganan Covid-19. https://www. covid19.go.id/situasi-virus-corona/

de Graff, H. (1986). Puncak kekuasaan Mataram: Politik ekspansi Sultan Agung. PT Pustaka Grafitipers.

Deshwal, V. K. (2020). COVID 19: A Comparative study of Asian, European, American continent. International Journal of Scientific Research and Engineering Development, 3(2).

Djalante, R. et al. (2020). Review and analysis of current responses to Covid-19 in Indonesia: Period of January to March 2020. Progress in Disaster Science, 6(100091).

Hakim, L. (2020). Budi Karya: Virus Covid-19 tidak masuk Indonesia karena "nasi kucing." 17 Februari 2020 19:24 WIB. https://www.antaranews.com/ berita/1302390/budi-karya-virus-covid-19-tidak-masuk-indonesia-karenanasi-kucing

Ihsanuddin. (2020). Menkes: Percuma yang sehat pakai masker. 02 Maret 2020. https://nasional.kompas.com/read/2020/03/02/15541281/menkespercuma-yang-sehat-pakai-masker

Kushandajani, K. (2014). Aplikasi community governance dalam pengelolaan program penanggulangan kemiskinan. Politika: Jurnal Ilmu Politik, 4(1), 41-48.

Kustiningsih, W. \& N. (2020). Penguatan modal sosial dalam mitigasi Covid-19. In Tata Kelola Penanganan Covid-19 di Indonesia: Kajian awal (pp. 179-193).

McKinlay P., Pillora, S., Tan, S.F., Von Tunzelmann, A. (2011). Evolution in community governance: Building on What Works.

Moleong, L. J. (2001). Metodologi penelitian kualitatif. Remaja Rosdakarya.

Nastiti, T. S. (2016). Perempuan Jawa: Kedudukan dan peranannya dalam masyarakat abad VII-XV. PT Dunia Pustaka Jaya.

Pratomo, K. T. (2019). Sidang syuro: Melacak praktik community governance di masyarakat Desa Jumo Kabupaten Temanggung. Journal of Politic and Government Studies, 8(1).1-10.

Raffles, S. T. S. (1830). The history of Java. John Murray, Albemarle Street.

Republika.co.id. (2020). ICJR: Program asimilasi narapidana harusnya diperbanyak. Republika.Co.Id.https://republika.co.id/berita/q8vzz5428/ 
Community governance with habitus in bonding to prevent SARS-CoV-2 pandemic ... (Tiyas Nur Haryani)

icjr-program-asimilasi-narapidana-harusnya-diperbanyak

Riana, I. K. (2009). Kakawin desa warnanna uthawi nagara kertagama: Masa keemasan Majapahit. Penerbit Kompas.

Sudarmo. (2015). Menuju model resolusi konflik berbasis governance. Sebelas Maret University Press.

Sugiyono. (2014). Memahami penelitian kualitatif. Alfabeta

Telaumbanua, D. (2020). Urgensi pembentukan aturan terkait pencegahan Covid-19 di Indonesia. Qalamuna Jurnal Pendidikan, Sosial, Dan Agama, 12(1), 59-70.

Walcott, A. S. (1914). Java and Her Neighbours: A traveller's notes in Java, Celebes, the Moluccas and Sumatra. G.P. Putnam's Sons.

Widaningrum, A. \& W. M. (2020). Dinamika respons pemerintah nasional: Krisis kebijakan penanganan Covid-19. In Tata kelola penanganan Covid-19 di Indonesia: Kajian awal (pp. 46-63).

World Health Organization. (2020). WHO coronavirus disease (Covid-19) dashboard. https://covid19.who.int/

Wu X, Cai Y, Huang X, Yu X, Zhao L, Wang F, et al. (2020). Co-infection with SARS-CoV-2 and influenza a virus in patient with pneumonia, China. Emerg Infect Dis, 26(6) 1324-1326. 
Journal of Social Studies (JSS), Volume 17, Number 2, 2021: 179-196 